\title{
Rate-Determining Steps of Cooking Reactions in Sprucewood Digestion with Acid Sulfite Liquors
}

\author{
Tsutomu Suzuki, ${ }^{*}$ Kunio Tosaka** and Jisuke Hayashi** \\ 酸性サルファイト法エゾマツ蒸解における \\ 蒸解反応の律速段階
}

北見工業大学鈴木 勉*

北海道大学工学部 戸坂图夫**, 林 治助**

\begin{abstract}
Cooking data from sprucewood digestions with liquors of $\mathrm{SO}_{2}-\mathrm{MgSO}_{4}$ bicomponents and of $\mathrm{Mg}$-base sulfite were analyzed in terms of basic heterogeneous kinetics to estimate rate-determining steps of two major cooking reactions, i. e., delignification and dissolution of carbohydrates.

Both cooking systems were found to be quite similar in progress modes of the reactions excepting their rates. That is, delignification by either cooking liquor proceeded in such a way that both steps of diffusion of the liquor to solid surface and chemical reaction between the solid reactant and the liquor would play roles as the rate-controlling stage in an early cooking period up to about $60 \sim 70 \%$ delignification. While in the latter period, diffusion of soluble lignin fragments as the reaction product into the liquor seemed to become the dominant factor.

On the other hand, dissolution of carbohydrates may be governed by diffusion of degraded hemicellulose fractions from reaction place for the first-half period of cooking and by chemical reaction step alone or together with the cooking liquor diffusion for the latter-half, respectively.

Sush view of rate-determining step can be supported by differences in the reaction rates, development of porous structure of wood cell wall and average molecular weight of dissolved lignin between the two cooking liquor systems.
\end{abstract}

先に行なった $\mathrm{SO}_{2}-\mathrm{MgSO}_{4}$ 二成分法, および $\mathrm{Mg}$ ベースサルファイト法のエゾマツ蒸解データを用い て, 両法の蒸解反応 (脱リグニン, 脱炭水化物) の律速段階を簡単な不均一系反応モデルに基く速度論的 取り扱いから推定した。

両方の蒸解反応の進行模様は速度の点を除けば非常によく似ていた。すなわち, 脱リグニンについては 速度は $\mathrm{Mg}$ ベース法の方が速いが, 両法ともに蒸解前半では蒸解液の固体表面への拡散と化学反応, 後 半では反応生成物の蒸解液本体への拡散によって反応が支配されるようである。一方, 眖炭水化物反応も 脱リグニンと同様に蒸解途中で進行樣相が変化するが, 前半では反応生成物の拡散, 後半では化学反応単 独あるいはこれと蒸解液の拡散の両ステップが律速段階になると考えられた。

こうした律速段階に関する推定結果が, 蒸解木粉の細胞壁の細孔構造変化や溶出リグニンの分子量変化

* Kitami Institute of Technology, Kitami 090

** Faculty of Engineering, Hokkaido University, Sapporo 060

* 北見市公園町 165, 于 090

** 札幌市北区北 13 条西 8 丁目， $\mathbf{T} 060$ 
と比較対照された。蒸解反応の律速段階の変化, そして反応生成物の抎散律速といら状況が, 細胞壁の細 孔構造の発達のしかたに深く結びついているといら結果は, 上述の律速段階についての推定を満足させる と考えられる。

\section{Introduction}

Reactions of wood chemical pulping proceed in a solid-liquid heterogeneous system in which two macromolecular components of wood, i. e., lignin and carbohydrates, are simultaneously removed with their degradations to soluble fractions in a cooking liquor. Sush progress of pulping reactions is considered to consist of the following three steps :

1) Diffusion of active ion species in the liquor to the surface of the wood solid reactant

2) Surface chemical reaction between the ion species and the solid reactant

3) Diffusion of reaction product from reaction interface into bulk liquor

Since these steps occur in series, the slowest one does control the overall reaction rate as a rate-controlling step.

Up to date, a large number of papers has been published on the rates of wood cooking reactions in acid sulfite processes ${ }^{1 \sim 7)}$ However, most of their manners dealing with the rate are the same as in homogeneous systems. Hence for delignification, chemical reaction stage which can make lignin soluble described in 2) is exclusively regarded as important from the standpoint of dominant factor in the reaction. This concept on the rate-controlling step must be limited to the case that both diffusion steps of 1) and 3) take place with much faster rates than that of the chemical reaction:

We previously conducted cookings of sprucewood with liquors of $\mathrm{SO}_{2}-\mathrm{MgSO}_{4}$ bicomponents and $\mathrm{Mg}$-base sulfite to investigate the relation between delignification and dissolution of carbohydrates ${ }^{8)}$. In the report, the influence of the diffusion steps on the rates of cooking reactions was not evalu ated in detail because the reactions were analysed in terms of first-order kinetics with respect to the amount of solid reactant. Even at the present stage, there seems to be still much room to ex- amine to what extent the diffusion steps will affect the rates of reactions.

In this paper, we dealed with the cooking reactions from an essential viewpoint that they occur in a heterogeneous process in order to obtain useful informations on their rate-controlling steps. The results were discussed, compared with changes of wood cell wall structure and of average molecular weight of dissolved lignin during cooking.

\section{Kinetic treatment of cooking reactions}

\subsection{Kinetic data}

The data obtained in the previous digestion of sprucewood $^{9)}$ were used in this kinetic treatment. Some new data were added to these from supplemental experiments performed in the same way as the above digestion. Results on structural change of wood cell wall and on molecular weight of dissolved lignin also include the new ones.

Tables 1 and 2 summarize the kinetic data from the bicomponents and $\mathrm{Mg}$-base sulfite cookings, respectively. $x_{L}$ and $x_{C}$ in these tables are the reaction indices expressed as weight ratio of dissolved to original. To evaluate the substantial degree of dissolution of carbohydrates, $x^{\prime} c$ was calculated from an assumption that $\alpha$-Cellulose must not dissolve out during the cooking. The relation equation between $x_{C}$ and $x_{C}^{\prime}$ is given"

$$
x^{\prime} C=A /(A-B) \times x_{C}=1.9631 x_{C}
$$

where $A$ and $B$ are amounts of total carbohyd rates and $\alpha$-Cellulose in wood, respectively.

\subsection{Kinetic treatment}

Lignin and carbohydrate molecules are known to exist in their characteristic configurations and different distributions of concentration in each layer of wood cell tissue ${ }^{10 \sim 22)}$. Particularly, the accessibilities of secondary cell wall lignin and middle lamella lignin to sulfite liquors are reported to be significantly different through digestion under UV microphotography ${ }^{19) 23) 24}$. Although 
Table 1 Kinetic data of cooking with $\mathrm{SO}_{2}-\mathrm{MgSO}_{4}$ bicomponents liquor

\begin{tabular}{|c|c|c|c|c|}
\hline $\begin{array}{l}\text { Temp. } \\
\left({ }^{\circ} \mathrm{C}\right)\end{array}$ & $\begin{array}{l}\text { Time } \\
\text { (min.) }\end{array}$ & $\begin{array}{c}\text { Delignification }^{\bar{s}} \text {, } \\
x_{L}\end{array}$ & $\begin{array}{l}\text { Dissolution of }{ }^{\text {a) }} \\
\text { carbohydrates, } x_{C}\end{array}$ & $\begin{array}{c}\text { Corrected } \\
\text { dissolution, } x^{\prime} c^{\mathrm{b})}\end{array}$ \\
\hline & soaked $^{\text {c) }}$ & 0.070 & 0.073 & 0.143 \\
\hline \multirow[t]{12}{*}{127} & 0 & 0.166 & 0.138 & 0.271 \\
\hline & 15 & 0.264 & 0.199 & 0.391 \\
\hline & 30 & 0.342 & 0.233 & 0.457 \\
\hline & 45 & 0.412 & 0.260 & 0.511 \\
\hline & 60 & 0.475 & 0.276 & 0.542 \\
\hline & 90 & 0.592 & 0.298 & 0.585 \\
\hline & 120 & 0.685 & 0.325 & 0.639 \\
\hline & 150 & 0.757 & 0.349 & 0.685 \\
\hline & 180 & 0.820 & 0.371 & 0.728 \\
\hline & 240 & 0.900 & 0.414 & 0.812 \\
\hline & 300 & 0.947 & 0.448 & 0.879 \\
\hline & 360 & 0.974 & 0.472 & 0.926 \\
\hline \multirow[t]{11}{*}{137} & 0 & 0.182 & 0.167 & 0.327 \\
\hline & 10 & 0.272 & 0.225 & 0.442 \\
\hline & 20 & 0.365 & 0.266 & 0.522 \\
\hline & 30 & 0.450 & 0.296 & 0.582 \\
\hline & 40 & 0.535 & 0.315 & 0.619 \\
\hline & 60 & 0.697 & 0.341 & 0.669 \\
\hline & 90 & 0.824 & 0.391 & 0.767 \\
\hline & 120 & 0.896 & 0.437 & 0.858 \\
\hline & 150 & 0.941 & 0.465 & 0.912 \\
\hline & 180 & 0.967 & 0.483 & 0.948 \\
\hline & 210 & 0.985 & 0.497 & 0.976 \\
\hline
\end{tabular}

a) Expressed as (dissolved weight/original weight)

b) Calculated from an assumption that $\alpha$-Cellulose must not dissolve out during the cooking : $x^{\prime}{ }_{C}=1.9631 x_{C}$

c) Wood was soaked in the cooking liquor for $20 \mathrm{hr}$ at room temperature prior to digestion

such problems will become serious if precise analysis is required for the reaction rate, we shall boldly make assumptions to simplify the kinetic treatment procedure that either molecule of lignin or carbohydrate is a spherical particle in shape, having identical chemical reactivity at any place of the cell tissue.

The overall chemical pulping reaction will be written typically as follows :

$A$ (reactant of cooking liquor) $+b B$ (solid reactant in wood) $\longrightarrow p P$ (reaction product soluble in the liquor)

where $b$ and $p$ are stoichiometric constants.

The reaction progress is shown schematically in

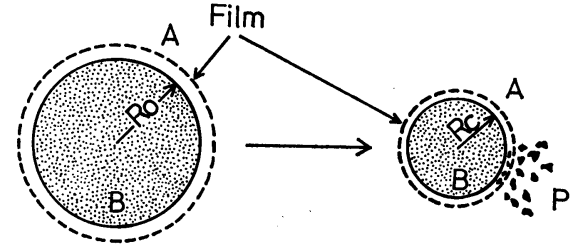
A : cooking liquor
Ro: Initial particle radius
B : Solid particle
P : Reaction product
Rc : Radius of particle

Fig. 1 Schematic representation of progress of pulping reactions.

Fig. 1 The change in radius of unreacted particle core, $r_{C}$, with the amount reacted, $d N_{B}$, of solid reactant $B$ is expressed by the stoichiometric 
Table 2 Kinetic data of cooking with $\mathrm{Mg}$-base sulfite liquor

\begin{tabular}{c|c|c|c|c}
\hline $\begin{array}{c}\text { Temp. } \\
\left({ }^{\circ} \mathrm{C}\right)\end{array}$ & $\begin{array}{c}\text { Time } \\
\text { (min.) }\end{array}$ & $\begin{array}{c}\text { Delignification } \\
x_{L}\end{array}$ & $\begin{array}{c}\text { Dissolution of } \\
\text { carbohydrates, } x_{C}\end{array}$ & $\begin{array}{c}\text { Corrected } \\
\text { dissolution, } x^{\prime} c\end{array}$ \\
\hline \multirow{3}{*}{127} & soaked $^{\text {c) }}$ & 0.061 & 0.067 & 0.132 \\
& 0 & 0.133 & 0.123 & 0.241 \\
& 15 & 0.224 & 0.181 & 0.355 \\
& 30 & 0.319 & 0.228 & 0.448 \\
& 45 & 0.397 & 0.259 & 0.508 \\
& 60 & 0.478 & 0.279 & 0.548 \\
& 90 & 0.624 & 0.305 & 0.599 \\
& 120 & 0.743 & 0.331 & 0.650 \\
137 & 150 & 0.838 & 0.369 & 0.724 \\
& 180 & 0.901 & 0.400 & 0.785 \\
& 210 & 0.994 & 0.424 & 0.832 \\
& 240 & 0.967 & 0.449 & 0.881 \\
& 0 & 0.167 & 0.167 & 0.328 \\
& 10 & 0.298 & 0.235 & 0.461 \\
& 20 & 0.410 & 0.274 & 0.538 \\
& 30 & 0.524 & 0.299 & 0.588 \\
& 40 & 0.650 & 0.330 & 0.647 \\
60 & 0.821 & 0.378 & 0.743 \\
& 75 & 0.881 & 0.408 & 0.801 \\
& 90 & 0.923 & 0.429 & 0.843 \\
120 & 0.971 & 0.463 & 0.908 \\
150 & 0.990 & 0.483 & 0.948 \\
\hline
\end{tabular}

a) Expressed as (dissolved weight/original weight)

b) Calculated from an assumption that $\alpha$-Cellulose must not dissolve out during thecooking : $x^{\prime} c=1.9631 x_{C}$

c) Wood was soaked in the cooking liquor for $20 \mathrm{hr}$ at room temperature prior to digestion

Equation (1)

$$
\begin{aligned}
-d N_{B} & =-b d N_{A}=-\rho_{B} d V=-\rho_{B} d\left(\frac{4}{3} \pi r_{C}^{3}\right) \\
& =-4 \pi r_{C}^{2} \cdot \rho_{B} \cdot d r_{C}
\end{aligned}
$$

where $\rho_{B}$ and $V$ are density of $B$ and volume of single solid particle, respectively.

1) A case that diffusion of $\mathrm{A}$ ingredient to the surface of $B$ becomes the rate-determining step $^{25}$

The consumption rate of $\mathrm{A},-d N_{A} / d t$, is given by Eq. (3)

$$
-\frac{d N_{A}}{d t}=k_{f} \cdot 4 \pi^{2} \cdot\left(c_{A L}-c_{A S}\right)
$$

where $k_{f}$ is the mass transfer coefficient between the solid and the fluid. $c_{A L}$ and $c_{A S}$ are the concentrations of $A$ in bulk liquor and at the solid surface. In steady state of this case, $c_{A S}$ is usually supposed to be zero. For $c_{A L}$, it can be taken as constant through the digestion due to high liquid to wood ratio of 10 in the experiment. The coefficient $k_{f}$ is significantly dependent on particle size as indicated in the following equation using $\phi\left(=r_{C} / r_{O}\right)$

$$
k_{f}=k_{f o} / \phi^{n}
$$

where $k_{f o}$ is the value of initial particle radius at $r=r_{0}$. In the low range of Reynolds number $\left(N_{R e}, N_{R e}<6\right)$ in which Stokes law can be applied, $n=1$ for a free-settling spherical particle. (In the autoclave employed in the experiment, the relative motion velocity between wood solid and cooking liquor can be neglected, i. e., $N_{R e}$ is substantially zero.) 
Eq. (3) is therefore rewritten in terms of the consumption rate of $B$ by using Eqs. (2) and (4)

$$
\begin{aligned}
-\frac{d N_{B}}{d t} & =-4 \pi_{c}{ }^{2} \cdot \rho_{B} \cdot \frac{d r_{c}}{d t} \\
& =\frac{b k_{f o}}{\left(r_{c} / r_{o}\right)} \cdot 4 \pi r_{c}{ }^{2} \cdot c_{A L}
\end{aligned}
$$

From the last two items, Eq. (6) can be obtained, separating the variables

$$
-\left(r_{c} / r_{o}\right) d r_{c}=\frac{b k_{f o} \cdot c_{A L}}{\rho_{B}} d t
$$

with $r=r_{o}$ at $t=0$ and $r=r_{c}$ at $t=t$ as conditions, integration of Eq. (6) yields

$$
1-\left(r_{c} / r_{o}\right)^{2}=\frac{2 b k_{f o} \cdot c_{A L}}{\rho_{B}} t
$$

There is a relationship between the reaction index of $B, x$, and $\mathrm{r}_{c}$ as follows :

$$
x=\frac{V_{o}-V_{c}}{V_{o}}=1-\left(r_{c} / r_{o}\right)^{3}
$$

where $V_{o}$ and $V_{c}$ are the volumes of initial sphere particle and of unreacted particle, respectively.

By combination of Eq. (7) with Eq. (8), we can obtain

$$
\frac{2 b k_{f o} \cdot c_{A L}}{\rho_{B} \cdot r_{o}} t=1-(1-x)^{2 / 3}=F_{1}(x)
$$

When the reaction is dominated by the diffusion step of $\mathrm{A}$, the plots of $\left[1-(1-x)^{2 / 3}\right]$ against $t$ should give a straight line whose slope, $2 b k_{f o}$. $c_{A L} / \rho_{B} \cdot r_{o}$, can be the apparent rate constant.

2) A case that surface chemical reaction of $A$ with $B$ becomes the rate-determining step ${ }^{25}$ )

In this situation $c_{A L}=c_{A S}$, since resistance for the diffusion of $A$ can be ignored. The rate of chemical reaction at the solid surface is usually proportional to the contact area between the solid and the fluid with a postulation that the reverse reaction does not take place. The reaction rate can be thus expressed on the basis of unit surface area of solid particle

$$
\begin{aligned}
-\frac{1}{4 \pi r_{c}^{2}} \cdot \frac{d N_{B}}{d t} & =-\frac{b}{4 \pi r_{c}^{2}} \cdot \frac{d N_{A}}{d t} \\
& =b k_{s} c_{A L}
\end{aligned}
$$

where $k_{s}$ is the first-order rate constant per unit surface area.

Substitution of $d N_{B}$ into $d r_{c}$ and then integration of Eq. (10) yields finally

$$
\frac{b k_{s} \cdot c_{A L}}{\rho_{B} \cdot r_{o}} t=1-(1-x)^{1 / 3}=F_{2}(x)
$$

Eq. (11) is the rate expression in the case that chemical reaction step controlles the overall process.

3) A case that diffusion of reaction product, $P$, is the rate-determining step

We shall suppose the situation that reaction products diffuse through their layer forming around the unreacted core into bulk liquor as shown in Fig. 2. This step will proceed with the rate proportinal to both the interfacial area and average concentration gradient of $P$ in the diffusion layer of thickness $d$. The rate of diffusion of $P$ can be therefore represented by

$$
-\frac{d N_{P}}{d t}=\frac{V^{\prime} d C_{P}}{d t}=D e \cdot 4 \pi r^{2}{ }_{c} \cdot \frac{\left(c_{P s}-c_{P}\right)}{d} \text { (12) }
$$

where $C_{P}$ and $C_{P s}$ are the concentrations of $P$ at the solid surface and its saturation. $V^{\prime}$ and $D e$ are volume of cooking liquor and the effective diffusion coeffient of $P$.

Replacement of $d N_{P} / d t$ by the consumption rate of $B$ gives

$$
\frac{d N_{P}}{d t}=-\frac{p}{b} \cdot \frac{d N_{B}}{d t}=\frac{p}{b} \cdot 4 \pi r^{3} \cdot \rho_{B} \cdot \frac{d x}{d t} \text { (13) }
$$

From Eqs. (12) and (13)

$$
d C_{P}=\frac{\frac{4}{3} \pi r^{3}{ }_{o} \cdot \rho_{B}}{V^{\prime}} \cdot d x \text { or } C_{P}=\frac{\frac{4}{3} \pi r^{3}{ }_{o} \cdot \rho_{B}}{V^{\prime}} \cdot x
$$

The value of $C_{P s}$ will be theoretically defined $\rho_{B}$ as the limiting concentration, and $d=r_{o}-r_{c}=$ $\left.r_{o}[1-x)^{1 / 3}\right]$ with the assumption.

By using these relations, Eq. (13) is rewritten in the form

$$
\begin{aligned}
\frac{p}{b} & \cdot \frac{4}{3} \pi r^{3}{ }_{o} \cdot \rho_{B} \cdot \frac{d x}{d t} \\
& =\frac{D e \cdot 4 \pi r^{2}{ }_{c} \cdot \rho_{B}}{r_{o}\left[1-(1-x)^{1 / 3}\right]}\left(1-\frac{\frac{4}{3} \pi r^{3} x}{V^{\prime}}\right)
\end{aligned}
$$

In this equation, the value of $\frac{4}{3} \pi r^{3}{ }_{c} \cdot x / V^{\prime}$ will be neglegible because $V^{\prime} \gg \frac{4}{3} \pi r^{3}{ }_{o}$, and hence Eq. (15) is obtained by separating the variables

$$
\frac{d x}{d t}=\frac{3 b D e}{p r_{o}^{2}} \cdot \frac{(1-x)^{2 / 3}}{\left[1-(1-x)^{1 / 3}\right]}
$$

Eq. (15) is easily integrated to give the following form

$$
\frac{2 b D e}{p r_{o}^{2}} t=\left[1-(1-x)^{1 / 3}\right]^{2}=F_{3}(x)
$$

This rate expression becomes the same form as the so-called Jander's equation ${ }^{26)}$. 


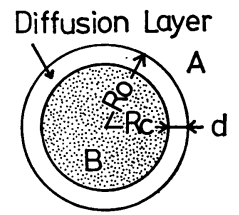

d : Thickness of diffusion layer

Fig. 2 Unreacted core model

\section{Results and Discussion}

\subsection{Process of delignification}

The values of $x_{L}$ in Tables 1 and 2 were substituted into Eqs. (9), (11) and (16) which should be applicable to each rate-controlling step to calculate $F_{1}\left(x_{L}\right), F_{2}\left(x_{L}\right)$ and $F_{3}\left(x_{L}\right)$. The results are shown in Fig. 3 for $\mathrm{SO}_{2}-\mathrm{MgSO}_{4}$ bicomponents liquor and in Fig. 4 for $\mathrm{Mg}$-base sulfite liquor,
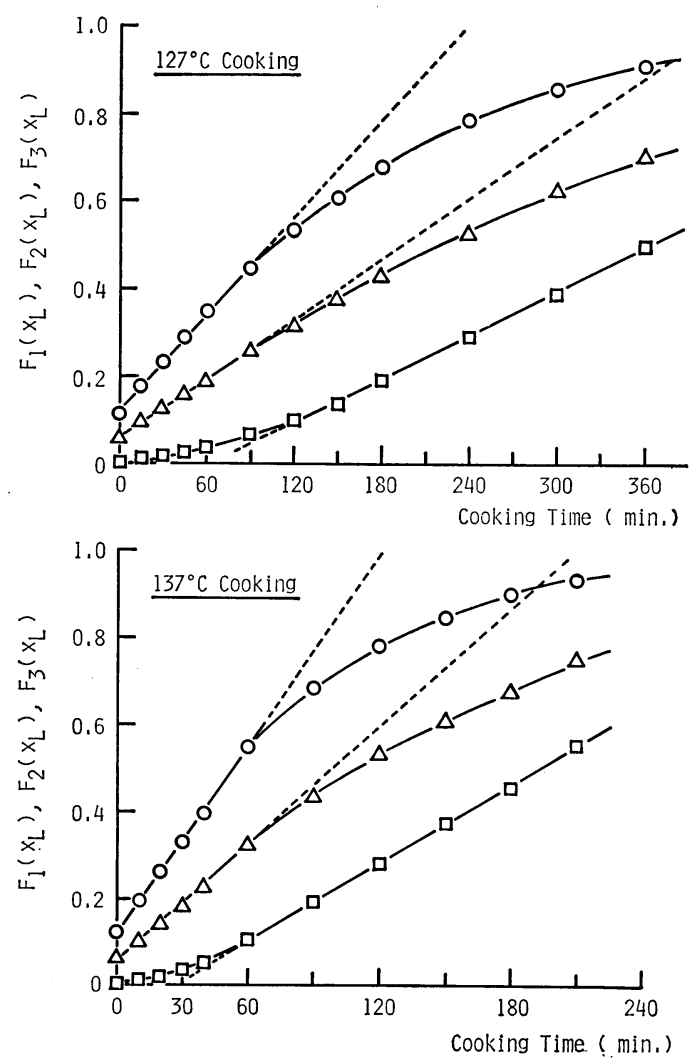

Fig. 3 Estimation of rate-determining step of delignification in $\mathrm{SO}_{2}-\mathrm{MgSO}_{4}$ bicomponents cooking

$\bigcirc: F_{1}\left(x_{L}\right), \Delta: F_{2}\left(x_{L}\right), \square: F_{3}\left(x_{L}\right)$
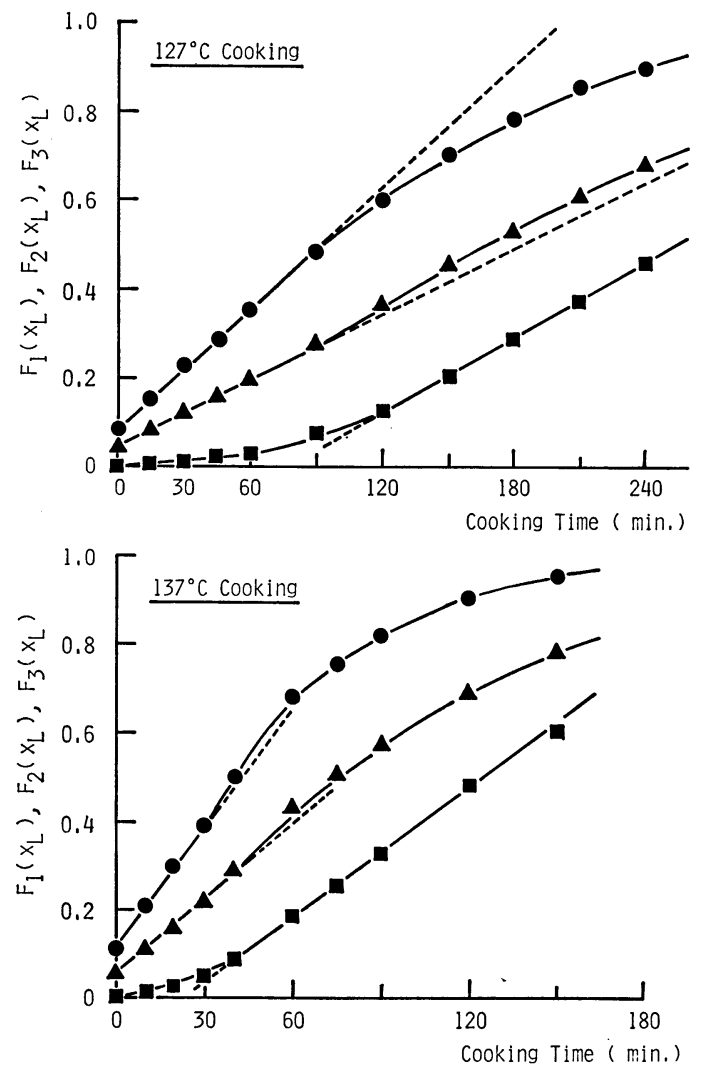

Fig. 4 Estimation of rate-determining step of delignification in $\mathrm{Mg}$-base sulfite cooking

$: F_{1}\left(x_{L}\right), \boldsymbol{\Delta}: F_{2}\left(x_{L}\right), \mathbf{\square}: F_{3}\left(x_{L}\right)$

respectively.

In the bicomponents system, the plots of $F_{1}\left(x_{L}\right)$ and $\mathrm{F}_{2}\left(x_{L}\right)$ against cooking time are found to give good straight lines in the first-half period up to about $60 \%$ delignification at either temperature of $127^{\circ} \mathrm{C}$ and $137^{\circ} \mathrm{C}$. On the contrary, $F_{3}\left(x_{L}\right)$ of both temperatures increase linearly with cooking time in the latter-half periods. Quite similar features to these are seen for $\mathrm{Mg}$-base sulfite in Fig. 4 From such situations of delignification, the process seems to be controlled by both steps of film diffusion of cooking liquor and of surface chemical reaction in an early cooking stage, whereas by diffusion of reaction product from solid surface in a later stage for either cooking system.

The mode change in progress of delignification during wood cooking with sulfite liquors has been recognized by several investigators from earlier 
times 1)314). They stated that the phenomenon could be attributable to the heterogeneity of wood lignin itself, as in a topochemical difference of split-off for secondary cell wall and middle lamella lignins ${ }^{19) 23) 24}$. In our previous digestion of sprucewood $^{8)}$, we also accepted the idea of heterogeneity of wood lignin to treat the whole delignification process divided into two reaction periods; early cooking stage and later one. But it should be emphasized that the possible non-homogeneity of wood lignin is not the sole candidate for interpretation on the rate change in delignification. In hetero-phase reactant systems of solid-fluid, the reactions take place at varying rate with the position of solid particle owing to different concentrations of the solid and the fluid. And whereby the rate-controlling step often shifts by the extent of the reaction. As these descriptions can be, of course, applied to wood cookings, the delignificaprocess will be regarded as a typical heterogeneous reaction dependent on complex wood cell tissues. Nevertheless a characteristic aspect of wood delignification in comparison to other solid-gas or solid-liquid reactions is pointed out by a wellknown fact that the average molecular weight of dissolved lignin increases steadily with increase of polydispersity as the reaction proceeds ${ }^{27)}{ }^{30)}$. Aside from theoretical explanations for the degradative

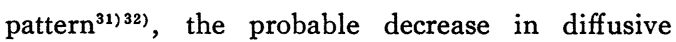
mobility of the soluble lignin fragment accompanied by the molecular increase will affect its releasing rate from the reaction site. Although the diffusion stage of reaction product is rarely thought to influence the overall rate in irreversible noncatalyzed heterogeneous systems, the above situation of delignification might make acceptable for government by the diffusion of soluble lignin molecules in the latter cooking stage.

Apparent rate constants and activation energies for each rate-controlling step determined from the slopes of straight line parts in Figs. 3 and 4 are given in Table 3, together with the extent of delignification.

In the first-half period of cooking at either temperature, the rate constants $k_{L, 1}$ and $k_{L, 2}$ corresponding to steps of 1 ) and 2) are larger in

Table 3 Apparent rate constants and activation energies calculated for each rate-determining step in delignification by liquor of $\mathrm{SO}_{2}-\mathrm{MgSO}_{4}$ bicomponents or $\mathrm{Mg}$-base sulfite

\begin{tabular}{|c|c|c|c|c|}
\hline $\begin{array}{l}\text { Temp. } \\
\left({ }^{\circ} \mathrm{C}\right)\end{array}$ & $\begin{array}{l}\text { Rate constant } \\
\left(\times 10^{-3} \mathrm{~min}^{-1}\right)\end{array}$ & $\begin{array}{c}\text { Extent of } \\
\text { delignification }\end{array}$ & $\begin{array}{r}\text { Activ } \\
\text { energy }\end{array}$ & $\begin{array}{l}\text { tion } \\
\text { (kcal) }\end{array}$ \\
\hline \multicolumn{5}{|c|}{$\left[\mathrm{SO}_{2}-\mathrm{MgSO}_{4}\right.$ bicomponents system $]$} \\
\hline $\begin{array}{l}127 \\
137\end{array}$ & $k_{L, 1}$ a) $\left\{\begin{array}{l}3.67 \\
7.05\end{array}\right.$ & $\left\{\begin{array}{l}\text { up to } 0.59 \\
\text { up to } 0.70\end{array}\right.$ & $E_{L, \theta}{ }^{\text {a) }}$ & 21.3 \\
\hline $\begin{array}{l}127 \\
137\end{array}$ & $k_{L, 2}$ b) $\left\{\begin{array}{l}2.23 \\
4.08\end{array}\right.$ & $\left\{\begin{array}{l}\text { up to } 0.59 \\
\text { up to } 0.70\end{array}\right.$ & $E_{L, 2}{ }^{\mathrm{b})}$ & 19.7 \\
\hline $\begin{array}{l}127 \\
137\end{array}$ & $k_{L, 3}{ }^{\mathrm{c})}\left\{\begin{array}{l}1.64 \\
2.94\end{array}\right.$ & $\begin{cases}\text { over } & \mathbf{0 . 6 9} \\
\text { over } & \mathbf{0 . 7 0}\end{cases}$ & $E_{L, 3}{ }^{\mathrm{c}}$ & 19.0 \\
\hline \multicolumn{5}{|c|}{ [Mg-base sulfite system] } \\
\hline $\begin{array}{l}127 \\
137\end{array}$ & $k_{L, 1}$ a) $\left\{\begin{array}{l}4.31 \\
9.17\end{array}\right.$ & $\left\{\begin{array}{l}\text { up to } 0.62 \\
\text { up to } 0.52\end{array}\right.$ & $E_{L, 1}{ }^{\text {a) }}$ & 24.6 \\
\hline $\begin{array}{l}127 \\
137\end{array}$ & $k_{L, 2}$ b) $\left\{\begin{array}{l}2.48 \\
5.33\end{array}\right.$ & $\left\{\begin{array}{l}\text { up to } 0.52 \\
\text { up to } 0.65\end{array}\right.$ & $\left.E_{L, 2}{ }^{\mathrm{b}}\right)$ & 24.9 \\
\hline $\begin{array}{l}127 \\
138\end{array}$ & $k_{L, 3}{ }^{\mathrm{c})}\left\{\begin{array}{l}2.74 \\
4.88\end{array}\right.$ & $\begin{cases}\text { over } & 0.74 \\
\text { over } & 0.65\end{cases}$ & $E_{L, 3}{ }^{\mathrm{c})}$ & 18.8 \\
\hline
\end{tabular}

It is the case that the reaction rate is controlled by the step of

a) diffusion of cooking liquor to the solid surface.

b) surface chemical reaction between the liquor and the solid.

c) diffusion of reaction products into the cooking liquor. 
Table 4 Comparison of ion species concentrations of $\mathrm{SO}_{2}-\mathrm{MgSO}_{4}$ bicomponents liquor with those of $\mathrm{Mg}$-base sulfite liquor at $130^{\circ}$ and $140^{\circ} \mathrm{C}$, respectively

\begin{tabular}{c|l|l}
\hline & \multicolumn{1}{|c|}{$\mathrm{SO}_{2}-\mathrm{MgSO}_{4}$ bicomponents $^{\text {a) }}$} & \multicolumn{1}{c}{$\mathrm{Mg}^{- \text {base sulfite }}{ }^{\mathrm{b})}$} \\
\hline $130^{\circ} \mathrm{C}$ & {$\left[\mathrm{H}^{+}\right]=7.38 \times 10^{-3} \mathrm{~mol} / l \quad(\mathrm{pH}=2.13)$} & {$\left[\mathrm{H}^{+}\right]=1.2 \times 10^{-3} \mathrm{~mol} / l \quad(\mathrm{pH}=\mathbf{2 . 9})$} \\
& {$\left[\mathrm{HSO}_{3}^{-}\right]=1.12 \times 10^{-1} \mathrm{~mol} / l$} & {$\left[\mathrm{HSO}_{3}^{-}\right]=4.3 \times 10^{-1} \mathrm{~mol} / l$} \\
$140^{\circ} \mathrm{C}$ & {$\left[\mathrm{H}^{+}\right]=5.27 \times 10^{-3} \mathrm{~mol} / l \quad(\mathrm{pH}=2.28)$} & {$\left[\mathrm{H}^{+}\right]=1.0 \times 10^{-3} \mathrm{~mol} / l \quad(\mathrm{pH}=3.0)$} \\
& {$\left[\mathrm{HSO}_{3}^{-}\right]=1.10 \times 10^{-1} \mathrm{~mol} / l$} & {$\left[\mathrm{HSO}_{3}^{-}\right]=3.9 \times 10^{-1} \mathrm{~mol} / l$} \\
\hline
\end{tabular}

a) $\mathrm{SO}_{2} 5.5 \mathrm{~g}+\mathrm{MgSO}_{4} 5.5 \mathrm{~g} / 100 \mathrm{~m} l$

b) $\mathrm{SO}_{2} 5.0 \mathrm{~g}+\mathrm{Mg}\left(\mathrm{HSO}_{3}\right)_{2} 1.0 \mathrm{~g} / 100 \mathrm{~m} l$

$\mathrm{Mg}$-base sulfite than those in the bicomponents. This will be mainly ascribed to the difference in concentration of $C_{A L}$ between the two liquors [see Eqs. (9) and (11)]. Because either $k_{L, 1}$ or $k_{L, 2}$ of $\mathrm{Mg}$-base sulfite is $1.10 \sim 1.17$ and 1.30 times that of bicomponent at $127^{\circ}$ and $137^{\circ} \mathrm{C}$ cookings, respectively.

Table 4 shows ion species concentrations of the two cooking liquors with the same compositions as used in this experiment at temperatures of $130^{\circ}$ and $140^{\circ} \mathrm{C}$.

For bicomponents liquor, the values were obtained on the basis of our earlier vapor pressure measurements ${ }^{33)}$. While for $\mathrm{Mg}$-base sulfite, they were calculated by using the data of direct $\mathrm{pH}$ determination by Ingruber ${ }^{34)}$. As given in this table, $\mathrm{Mg}$-base liquor is expected to have higher concentration of $\mathrm{HSO}_{3}{ }^{-}$, which is said to become important rather than $\left[\mathrm{H}^{+}\right]$at acidic cooking conditions to depress the degree of condensation reaction of lignin, compared to bicomponents In addition, the change of $\left[\mathrm{HSO}_{3}{ }^{-}\right]$with the temperature increase by $10^{\circ} \mathrm{C}$ seems to be more significant in $\mathrm{Mg}$-base sulfite than in bicomponents. Such conditions about $\mathrm{HSO}_{3}{ }^{-}$concentration will favorably account for the higher values of rate const.

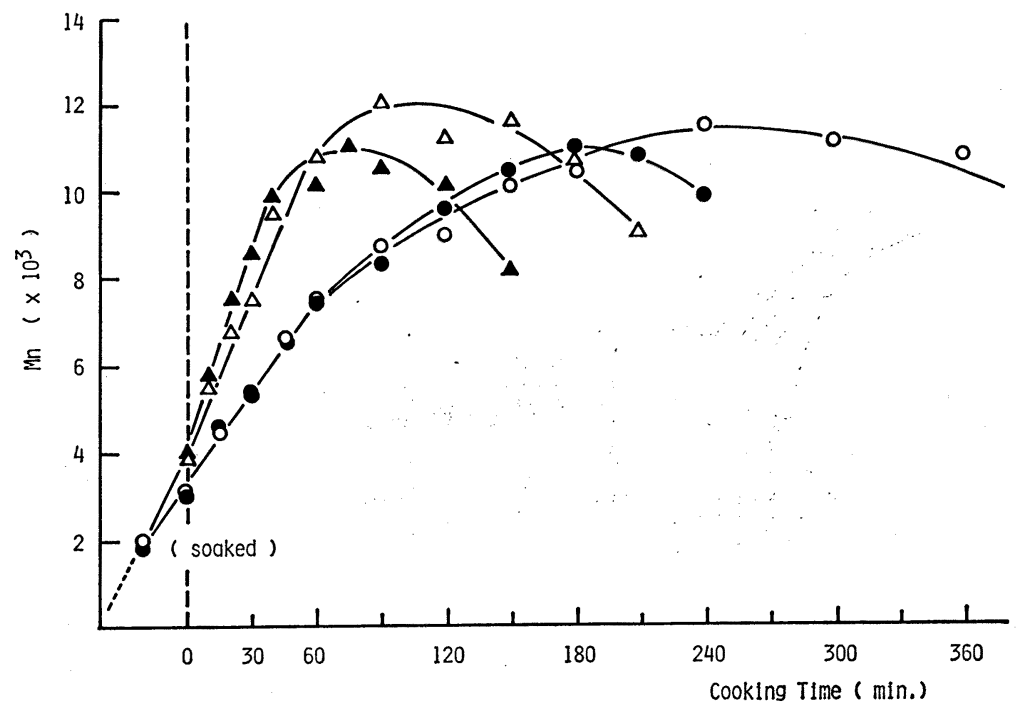

Fig. 5 Change of number average molecular weight $(\mathrm{Mn})$ of dissolved lignin with cooking time $\mathrm{O}: 127^{\circ} \mathrm{C}$

$\left.\Delta: 137^{\circ} \mathrm{C}\right\} \mathrm{SO}_{2}-\mathrm{MgSO}_{4}$ bicomponents

$\left.\begin{array}{r}\text { : }: 127^{\circ} \mathrm{C} \\ \mathbf{1} 137^{\circ} \mathrm{C}\end{array}\right\} \mathrm{Mg}$-base sulfite 

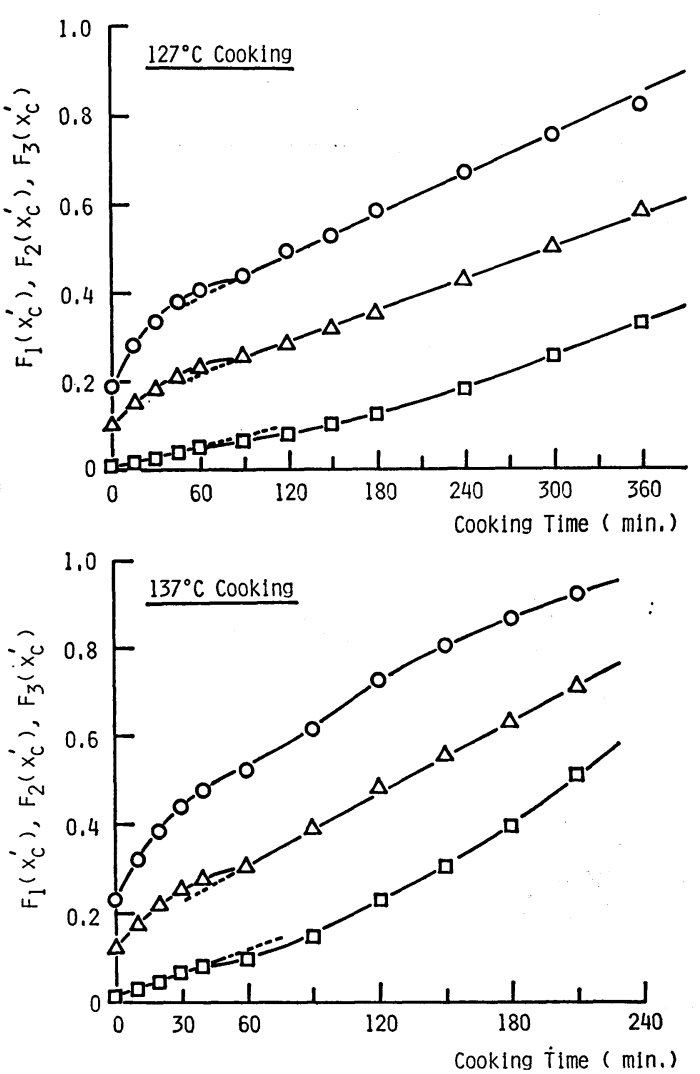

Fig. 6 Estimation of rate-determining step of dissolution of carbohydrates in $\mathrm{SO}_{2}-\mathrm{Mg}$ $\mathrm{SO}_{4}$ bicomponents cooking

$\bigcirc: F_{1}\left(x_{C}^{\prime}\right), \Delta: F_{2}\left(x^{\prime}{ }_{C}\right), \square: F_{3}\left(x^{\prime} C\right)$

ants as well as activation energies of $E_{L, 1}$ and $E_{L, 2}$ in $\mathrm{Mg}$-base liquor.

Even in the latter cooking stages at both temperatures, it is found that $\mathrm{Mg}$-base sulfite proceeded with higher rates of delignification than bicomponents. Since the rate constant $k_{L, 3}$ is a function of the effective diffusivity $D e$ according to Eq. (16), the problem of molecular weight of dissolved lignin mentioned precedently may come up as one possible factor giving rise to the difference in the rate between the two liquor systems.

From the plots of the number average molecular weight, Mn, of dissolved lignin against cooking time shown in Fig. 5, Mn tend to decrease over the periods when the diffusion step of soluble lignin fragments could control the overall rate at both temperature cookings with either liquor. This is probably due to the pronounced depoly-
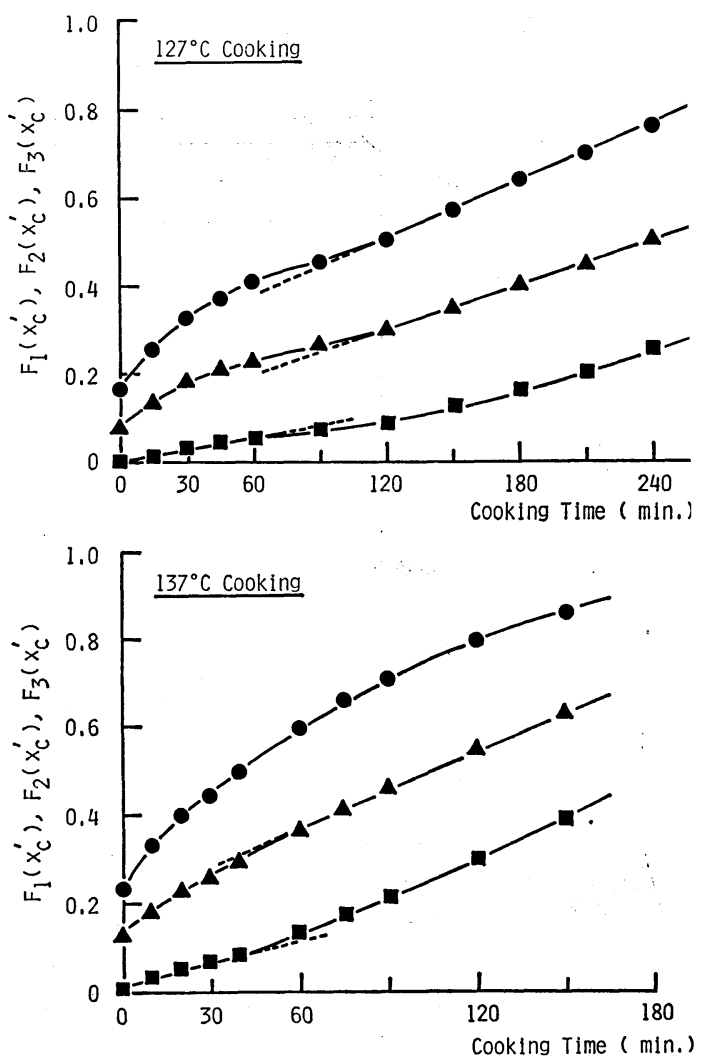

Fig." 7 Estimation of rate-determining step of dissolution of carbohydrates in $\mathrm{Mg}$-base sulfite cooking

$: F_{1}\left(x_{C}^{\prime}\right), \Delta: F_{2}\left(x_{c}^{\prime}\right), \square: F_{3}\left(x_{C}^{\prime}\right)$

merization of lignin fragments already dissolved out. However, we can draw, at least, the interpretation from the unfavorable result that there would not so much difference in molecular weight of dissolved lignin molecule between the two liquors even at the higher delignification level.

For lignosulfonate exhibiting poor swelling behavior in aqueous solutions ${ }^{35) 36}$, the effect of its molecular weight variation on the inherent diffu. sion coefficient is presumed to be very small particularly in the range of higher molecular weight 36) 38). The matter of the difference in the molecular weight between bicomponents and $\mathrm{Mg}$-base sulfite will not be serious enough to induce the above difference in rate, although it may be the reason why $k_{L, 3}$ can be considered constant in either cooking system despite the actual change of $D e$. 
Table 5 Apparent rate constants and activation energies calculated for each ratedetermining step in dissolution of carbohydrates by liquor of $\mathrm{SO}_{2}-\mathrm{MgSO}_{4}$ bicomponents or $\mathrm{Mg}$-base sulfite

\begin{tabular}{|c|c|c|c|c|}
\hline $\begin{array}{l}\text { Temp. } \\
\left({ }^{\circ} \mathrm{C}\right)\end{array}$ & $\begin{array}{l}\text { Rate constant } \\
\left(\times 10^{-3} \mathrm{~min}^{-1}\right)\end{array}$ & $\begin{array}{c}\text { Extent of } \\
\text { delignification }\end{array}$ & $\begin{array}{r}\text { Activ } \\
\text { energy }\end{array}$ & $\begin{array}{l}\text { (kcal) } \\
\text { (kcon }\end{array}$ \\
\hline \multicolumn{5}{|c|}{$\left[\mathrm{SO}_{2}-\mathrm{MgSO}_{4}\right.$ bicomponents system $]$} \\
\hline $\begin{array}{l}127 \\
137\end{array}$ & $k_{C, 1}{ }^{\text {a) }}\left\{\begin{array}{r}1.46 \\
-\end{array}\right.$ & $\left\{\begin{array}{r}\text { over } 0.59 \\
-\end{array}\right.$ & $\left.E_{C, 1}{ }^{a}\right)$ & 一 \\
\hline $\begin{array}{l}127 \\
137\end{array}$ & $k_{C, 2}{ }^{\text {b) }}\left\{\begin{array}{l}1.13 \\
2.69\end{array}\right.$ & $\left\{\begin{array}{l}\text { over } 0.59 \\
\text { over } 0.70\end{array}\right.$ & $E_{C, 2}{ }^{\text {b) }}$ & 28.3 \\
\hline $\begin{array}{l}127 \\
137\end{array}$ & $k_{C, 3}{ }^{\mathrm{c})}\left\{\begin{array}{l}0.78 \\
1.58\end{array}\right.$ & $\left\{\begin{array}{l}\text { up to } 0.48 \\
\text { up to } 0.54\end{array}\right.$ & $E_{C, 3}{ }^{\mathrm{c})}$ & 22.8 \\
\hline \multicolumn{5}{|c|}{ [Mg-base sulfite system] } \\
\hline $\begin{array}{l}127 \\
137\end{array}$ & $k_{C, 1}{ }^{\text {a) }}\left\{\begin{array}{r}2.08 \\
-\end{array}\right.$ & $\left\{\begin{array}{r}\text { over } 0.74 \\
-\end{array}\right.$ & $E_{C, 1}{ }^{\text {a) }}$ & 一 \\
\hline $\begin{array}{l}127 \\
137\end{array}$ & $k_{C, 2}{ }^{\text {b) }}\left\{\begin{array}{l}1.70 \\
3.24\end{array}\right.$ & $\left\{\begin{array}{l}\text { over } 0.74 \\
\text { over } 0.82\end{array}\right.$ & $\left.E_{C, 2}{ }^{\mathrm{b}}\right)$ & 21.0 \\
\hline $\begin{array}{l}127 \\
137\end{array}$ & $k_{C, 3}{ }^{\mathrm{c})}\left\{\begin{array}{l}0.82 \\
1.68\end{array}\right.$ & $\left\{\begin{array}{l}\text { up to } 0.48 \\
\text { up to } 0.65\end{array}\right.$ & $E_{C, 3}{ }^{\mathrm{c})}$ & 23.3 \\
\hline
\end{tabular}

It is the case that the reaction rate is controlled by the step of

a) diffusion of cooking liquor to the solid surface.

b) surface chemical reaction between the liquor and the solid.

c) diffusion of reaction products into the cooking liquor.

Activation energies with values as high as about 19 kcal suggest the participation of more important factor other than the molecular weight.

\subsection{Process of dissolution of \\ carbohydrates}

The same calculations as in delignification were conducted, using the corrected index, $x^{\prime} c$, in Tables 1 and 2. $F_{1}\left(x^{\prime} c\right), F_{2}\left(x^{\prime} c\right)$ and $F_{3}\left(x^{\prime} c\right)$ are plotted against cooking time in Figs. 6 and 7 for bicomponents and $\mathrm{Mg}$-base sulfite, respectively.

In first-half periods of both cooking liquors, the reactions seem to be rate-controlled by the diffusion of reaction products, i. e., soluble degraded hemicellulose fractions. Whereas in the latterhalf periods, both steps of chemical reaction and diffusion of cooking liquor for $137^{\circ} \mathrm{C}$ cooking and a single step of the former for $127^{\circ} \mathrm{C}$ cooking will play roles in determining the rate. This reaction is thus found to take place with different modes for an initial and a latter periods similarly to the precedent delignification.

Carbohydrate components of wood dissolving during digestion comprise several kinds of hemicelluloses. Softwood hemicelluloses are mainly glucomannan and xylan which posses side chain groups such as methyl, acetyl, galactose, glucuronic acid and arabinose, etc. In acid sulfite liquors, it is known that the side chains easily hydrolyzed dissolve almost at an early cooking stage, and subsequently gradual splitting of the main chain occurres $^{39}$. This information may rationalize the change in mode of the dissolution reaction in a certain sense. But yet, the contact of hemicellulose molecules with cooking liquor relating to their distributions within wood cell tissues will become serious mostly for discussion, because the times of shift in rate-determining step at either temperature cooking of bicomponents as well as of $\mathrm{Mg}$-base sulfite agree approximately well with those of the corresponding delignification. This indicates that the two cooking reactions are closely associated with each other, probably reflecting the effect of structural change in wood cell wall on progress of the reactions as described later. 
The apparent values of rate constants and activation energies are given in Table 5 .

The situation of initial cooking periods that the diffusion of reaction products will be the dominant step may be explained by the higher rate of hydrolysis of hemicelluloses and at the same time high swelling of themselves in wood or their soluble fractions in the liquor. That is, the soluble fractions comparatively easily produced with degradation of hemicellulose molecules are imagined to be apt to gather around the reaction surf ace owing to their difficulties in mobility by spatial expansion ${ }^{40)}$. To high values of the activation energies, $E_{C, 3}$, in the diffusion-controlled region, it will be still necessary to apply the same interpretation as the delignification.

It the chemical reaction serves as the rate-determining in the latter cooking stages, the difference in $E_{C, 2}$ between the two liquors can be responsible for the greater change in hydrogen ion concentration of bicomponents than that of $\mathrm{Mg}$-base sulfite, as shown in Table 4 However, the rate constant of $k_{C, 2}$ is obviously larger at either temperature cooking in spite of lower concentration of $\mathrm{H}^{+}$. This will result from a considerable difference in $k_{s}$ of Eq. (11), which represents some inherent factor concerning chemical reactivity like available numbers of active site on solid surface in each solid-fluid system. Heavy degeneration of carbohydrates caused by the so-called "burnt cook" gives a good example that highly acidic cooking liquor is not necessarily effective to promote the dissolution reaction of carbohydrates. A further point to note is that the rate of chemical stage will be affected by the diffusion step of cooking liquor to the solid surface under the circumstances of their successive processes. The difference in $k_{C, 2}$ between the $127^{\circ} \mathrm{C}$ cookings is really to found to be almost equal in that of $k_{C, 1}$. $k_{C, 1}$ is dependent on the coefficient $k_{f o}$ from Eq. (9). The mass transfer coefficient can be often substituted for more convenient expression, "permeability of cooking liquor into wood tissues" in wood pulping. Better permeability of $\mathrm{Mg}$-base liquor compared to bicomponents liquor will possibly lead to higher rates of not only the chemical reaction but also of the overall process for dissolution of carbohydrates as well as delignification. So long as wood cookings are conducted in a heterogeneous system of solid-liquid, the subject of the mass transfer will involve some critical aspects connected with wood pulping capability of cooking liquor.

\subsection{Effect of structural change in wood cell wall on progress of cooking reactions}

According to back diffusion mechanism proposed for removal of the cell wall lignin ${ }^{23) 41) ~ 44)}$ their soluble fragments must diffuse through the cell wall pore towards cell lumen into cooking liquor to dissove out. Under such circumstances of delignification, the cell pore always acts as a sieve specifying the size (or molecular weight in other words) of soluble lignin fragment and thereby limits its duffusive mobility within the cell wall. We already noticed the validity of the mechanism from an intimate relation between the cell wall pore and molecular weight of dissolved lignin"). The purpose in this study is, however, to examine what extent the cell wall structure affects the rates of cooking reactions. As stated above, the activation energies obtained in cases of rate-controlling step by the diffusion of reaction products appear a little too large as for changes of their own diffusion coefficients with temperature. These will be closely related to the diffusive behaviors probably influenced by the structural change of wood cell wall during digestion.

The values of median pore width (MWP for brevity) which is the pore width at one half the cell wall pore volume ${ }^{42)}$, suitable as a measure of the porous structure change are plotted against cooking time for woods digested with bicomponents and $\mathrm{Mg}$-base sulfite liquors in Fig. 8.

For both liquor systems, MPW increase linearly with larger slope in the first-half than in the latter-half cooking periods. The less increases of MPW in the latter stages are quite natural because of absolutely small dissolving quantities of wood components. It is particulary noteworthy that the times of change in the slope of MPW coincide well with those of the shift in rate-determining 


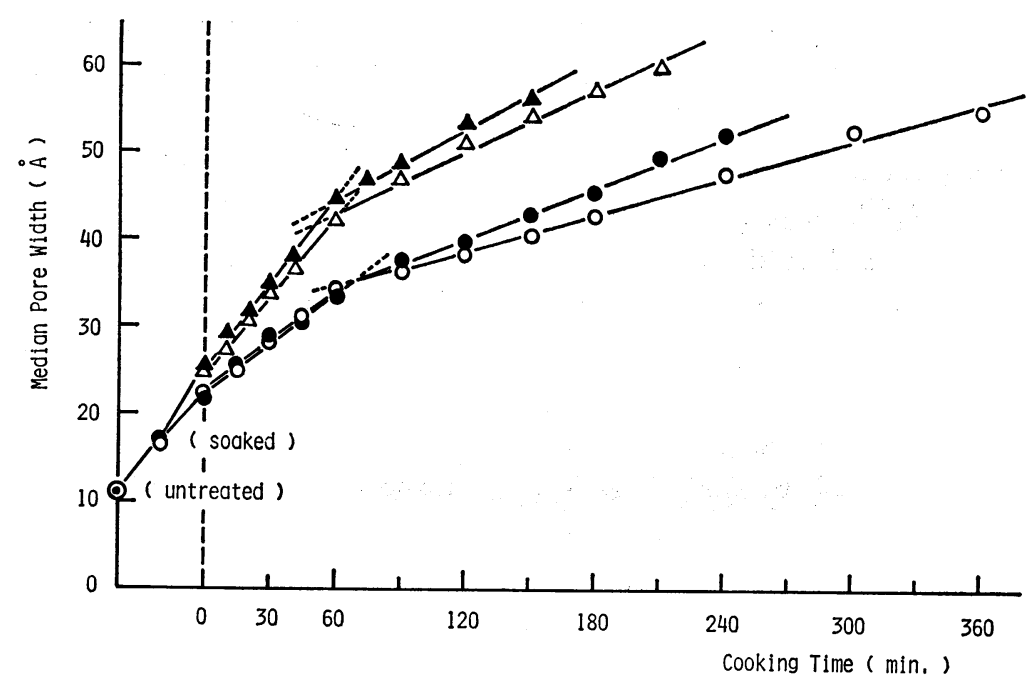

Fig. 8 Change of Median pore width of digested meal with cooking time

$$
\begin{aligned}
& \left.\begin{array}{l}
\mathrm{O}: 127^{\circ} \mathrm{C} \\
\Delta: 137^{\circ} \mathrm{C}
\end{array}\right\} \mathrm{SO}_{2}-\mathrm{MgSO}_{4} \text { bicomponents } \\
& \left.\begin{array}{l}
\text { : }: 127^{\circ} \mathrm{C} \\
\text { : }: 137^{\circ} \mathrm{C}
\end{array}\right\} \mathrm{Mg} \text {-base sulfite }
\end{aligned}
$$

step for removals of lignin and carbohydrates. It will be poined out expectedly from these results that the situation of rate-control by the diffusion of reaction products or the shift of rate-determining step should be by no means independent on the porous structure development.

In the early stage of cooking with either liquor, the increasing rate of MPW is found to be approximately doubled for the $10^{\circ} \mathrm{C}$ rise in temperature similarly to the case of the rate constant $k_{C, 3}$ for dissolution of carbohydrates. The enlargement of the cell pore width will thus result in a proportional decrease of resistance for the diffusion of soluble hemicellulose fractions through the cell wall pore to advance the dissolution reaction. The concept of the back diffusion is, of course, applicable for removal of carbohydrates molecules existing in the cell wall. Although quite similar trends' in the increase of MPW to Mn given in Fig. 5 are observed for these cooking periods, the more important steps of 1) and 2) for delignification may come from the conditions that the cell pore width increases relatively largely and the soluble fragments produced are not still so bulky.
While in the latter stages, the slopes of MPW become roughly 1.4 times for the $10^{\circ} \mathrm{C}$ rise. This figure seems to satisfy the increase in $k_{L, 3}$ of delignification by about 1.8 times when the change of inherent diffusion of soluble lignin molecule with temperature is taken into account. At higher delignification level with high molecular weight lignin fractions released from wood lignin gel-network, the cell pore will exert the significant barrier effect by its smaller increase in width than that of the lignin fragment. The actual excess depolymerization of dissolved lignin as seen in Fig. 5 may partly reflect the diffusive difficulty of soluble fragments through the cell wall pore in a different point of view. However, the dissolution of carbohydrates appear to be no longer affected by such structural change of cell wall. During this level of cooking, the cell pore width attained already adequately high value and hemicellulose molecules remaining in wood would be decomposed considerably by longer time attack of $\mathrm{H}^{+}$. That is, their soluble fractions produced will be small enough to pass through the cell pore smoothly in contrast with delignification. 


\section{Conclusions}

In this report, rate-determining steps of cooking reactions of sprucewood with acid sulfite liquors were estimated from a heterogeneous kinetic analysis using a simple sphere model. This kinetic treatment is not complete enough to deal with the problem of diffusion through wood cell wall as a barrier or different splitting pattern between secondary cell wall and middle lamella lignins ${ }^{19}$ 23)24). But then the results will indicate that both diffusion steps of cooking liquor to the solid surface and of reaction products to the liquor are as important as chemical reaction step which makes wood components solubilize. On the contrary, Procter et al. stated from UV microscopic observations of digested woods that the both diffusion steps would not become dominant factors of delignification $^{23)}$. We think their approach to be not a successful method to judge whether the diffusion steps have effects on the rates of cooking reactions or not. In fact, the progress of cooking reactions is greatly affected by the structural change of wood cell wall during cooking. It may safely be said that development of porous structure in wood cell wall will contribute to acceleration of the diffusion of cooking liquor, increase of effective contact area of solid reactants with cooking liquor, and consequently facility of the diffusion of reaction products. Accordingly, the overall rate expressions of cooking reactions had better include the factor concerning the change of cell wall structure as a function of cooking time. The experimental function will be characteristic of individual cooking system or of cooking conditions employed, and can be availabl for predicting of change in quality of wood pulp obtained with cooking degree.

\section{References}

1) G. Golgfinger : Paper Trade J., 112, No. 24, 29 (1941), 113, No. 15, 27 (1942)

2) S. Häggroth, B. O. Lindren and U. Saéden: Svensk Papperstidn., 56, 660 (1953)

3) D. H. Wilder and S. T. Han : Tappi., 45, 1 (1962)
4) E. F. Elton : ibid., 46, 404 (1963)

5) F. H. Yorston and N. Liebergott : Pulp Paper Mag. Can., 66, T-272 (1965)

6) I. Sakata and R. Senju : J. Chem. Soc. Jpn., Ind. Chem. Section, 62, 446, 454, 459 (1959)

7) B. Hagberg and N-H. Schöön : Svensk Papperstidn., 76, 561 (1973)

8) T. Suzuki, K. Tosaka and J. Hayashi : J. Chem. Soc. Jpn., Chem. \& Ind. Chem., 1980 (1), 96

9) T. Suzuki, K. Tosaka and J. Hayashi : Jpn. Tappi., 34, 493 (1980)

10) H. Meiyer : J. Polymer Sci., 51, 11 (1961)

11) O. L. Forgacs : Pulp Paper Mag. Can., 64, T89 (1963)

12) R. St. Manley : Nature, 204, 1155 (1964)

13) R. St. Manley and S. Inoue : Polymer Letters, 3, 691 (1965)

14) R. H. Marchessault : "Chim Biochim. Lignine, Cellulose et Hemicellulose", Grenoble (1964), pp. 287

15) I. B. Sach, I. R. Clark and J. C. Pew : J. Polymer Sci., C2, 203 (1963)

16) W. A. Côte, T. E. Timell and R. A. Zabel : Holz Roh. Werkstoff, 24, 432 (1966)

17) G. P. Berlyn and R. E. Mark : Forest Prod. J., 16, 140 (1965)

18) D. Fengel : Svensk Papperstidn,. 79, 24 (1974)

19) J.A.N. Scott, A. R. Procter, B. J. Fergus and D. A. I. Goring : Wood Sci. Technol., 3, 73 (1969)

20) B. J. Fergus, A. R. Procter, J.A.N. Scott and D. A. I. Goring : ibid., 3117 (1969)

21) J. R. Wood and D. A.I. Goring : Pulp Paper Mag. Can., 72, 61 (1972)

22) A. J. Kerr and D. A.I. Goring : Cellulose Chem. Technol., 9, 563 (1975)

23) A. R. Procter, W. Q. Yean and D. A. I. Goring: Pulp Paper Mag. Can., 68, T-445 (1967)

24) J. R. Wood, P. A. Ahlgren and D. A. I. Goring : Svensk Papperstidn., 71, 15 (1972)

25) T. Ohtake : "Chemical Engineering III", Iwanami Zensho 225, Tokyo (1978) pp. 149, K. Hashimoto : "Reaction Engineering", Baifukan, Tokyo (1979) pp. 230, etc. 
26) W. Jander : $Z$. anorg. allgem. Chem., 163, 1 (1927)

27) V.F. Felicetta, A. Ahola and J. L. McCarthy: J. Am. Chem. Soc., 78, 1899 (1956)

28) E. Nokihara, M. J. Tuttle, V. F. Felicetta and J. L. McCarthy : ibid., 79, 4495 (1957)

29) D. A. I. Goring and A. Rezanowich : Can. J. Chem., 36, 1653 (1958)

30) W. Q. Yean and D. A. I. Goring : Pulp Paper Mag. Can., 65, T-217 (1964)

31) P. J. Flory: Principles of Polymer Chemis. try", Cornell University Press, New York (1953) pp. 321, 393

32) A. Szabo and D. A. I. Goring, Tappi., 51, 440 (1968)

33) T. Suzuki, K. Tosaka and J. Hayashi : J. Jpn. Wood Res. Soc., 24, 479, 489 (1978)

34) O. V. Ingruber: Pulp Paper Mag. Can., 66, T-215 (1965)

35) I. Tachi, Y. Nakai, S. Ohtsuki and Y. Kojima : Jpn. Tappi., 14, 253 (1958)
36) W. Q. Yean, A. Rezanowich and D. A. I. Goring: "Chim. Biochim. Lignine, Cellulose et Hemicellulose", Grenoble (1964) pp. 327

37) J. L. Gardon and S. G. Mason : Can. J. Chem., 33, 1491 (1955)

38) D. A. I. Goring : Pure Applied Chem., 5, 233 (1962)

39) S. A. Rydholm : "Pulping Processes", Interscience (1965) pp. 507

40) R. E. Lebel and D. A. I. Goring : J. Polymer Sci., C2, 29 (1963)

41) A. B. Wardrop : Svensk Papperstidn., 66, 231 (1963)

42) J. E. Stone and A. M. Scallan : J. Polymer Sci., C11, 13(1965), Tappi., 50, T-496(1967), Pulp Paper Mag. Can., 69, T-208 (1968)

43) J. Q. McNaughton, W. Q. Yean and D. A.I. Goring : Tappi., 50, 548 (1967)

44) P. A. Ahlgren, W. Q. Yean and D. A. I. Goring : Tappi,. 54, 737 (1971) 